\title{
Food-web structure and functioning of temperate and tropical lakes: A stoichiometric viewpoint
}

\author{
Michael Danger ${ }^{1,2 *}$, Gérard Lacroix ${ }^{3}$, Samba Kâa ${ }^{4}$, El Hadji Ndour ${ }^{4}$, Daniel Corbin ${ }^{4}$ \\ and Xavier Lazzaro 4,5 \\ ${ }^{1}$ UMR CNRS 8079 - ESE, Laboratoire de Systématique, Écologie et Évolution, Université Paris Sud XI, Bât. 362, 91405 Orsay, \\ France \\ 2 Current address: Laboratoire d'Écologie Fonctionnelle, Ecolab UMR 5245, CNRS, 29 rue Jeanne Marvig, 31055 Toulouse, France \\ ${ }^{3}$ Laboratoire Bioemco, UMR 7618 (Université Paris 6, CNRS, INRA, ENS), École Normale Supérieure, 46 rue d'Ulm, 75230 Paris \\ Cedex 05, France \\ ${ }^{4}$ IRD, UR167-CYROCO, Campus mixte ISRA-IRD Bel-Air, BP 1386, CP 18524, Dakar, Senegal \\ ${ }^{5}$ Current address: UR 131-AMAZONE, UMR 5178-BOEA-USM 0401, CP 53, 61 rue Buffon, 75231 Paris Cedex 5, France
}

Received 17 June 2008; Accepted 2nd October 2008

\begin{abstract}
Difficulties to simply transfer trophic cascade theory from temperate to tropical lakes are now well recognized. Many mechanisms trying to explain top-down divergences between these systems have been proposed, such as lack of key species of herbivorous zooplankton, absence of seasonality in fish reproduction, cyanobacteria development, or differences in fish foraging behaviour. Very few studies have considered bottom-up mechanisms, in particular differences in nutrient recycling and nutrient limitation between the two types of ecosystems. According to the ecological stoichiometry theory, fish-induced alterations of food-web structure could modify the efficiency of consumer-driven nutrient recycling by changing the relative biomass contribution of species in food webs. Consequently, by mostly considering top-down processes, one could underestimate consequences on nutrient availability for phytoplankton growth. In this paper, we compared the results of two mesocosm experiments carried out in temperate and tropical areas, each manipulating foodweb structure via the presence or absence of fish. We found trophic cascades in both experiments, but differences between fishless and fish treatments were greater in temperate than in tropical systems. In the tropical experiment, the observed effects could not be supported by classical zooplankton community alteration or by cyanobacteria prevalence. Our results suggest a key contribution of fish nitrogen-excretion to phytoplankton growth in mostly nitrogen-limited tropical systems. Differences in stoichiometric response to food-web structure alteration between temperate and tropical lakes could thus represent a major difference between the two systems. Our study stresses the need for further studies that would allow robust generalization on the functioning of freshwater temperate and tropical ecosystems.
\end{abstract}

Key words: Ecological stoichiometry / tropical vs. temperate / trophic cascades / nutrient recycling / omnivory

\section{Introduction}

It is now well recognized that top predators can influence the whole food-web structure and biomass, down to the primary producers. Mechanisms of these 'topdown' effects, classically referred as 'trophic cascades', have received much attention during the last two decades in both aquatic and terrestrial systems (see Polis, 1999;

\footnotetext{
*Corresponding author.

E-mails: danger@cict.fr; lacroix@biologie.ens.fr;

ka@ird.sn; corbin@ird.sn; lazzaro@mnhn.fr
}

Polis et al., 2000; Schmitz et al., 2000). Polis (1999) differentiated 'species-level cascades' and 'community-level cascades'. In species-level cascades, changes in predators affect the abundance of only few species of primary producers, while community-level cascades alter the overall distribution of plant biomass throughout an entire system (see also Polis et al., 2000). Yet, community-wide effects have mainly been established for aquatic temperate ecosystems. In particular, reduction of zooplanktivorous and omnivorous fish often leads to decrease in phytoplankton total biomass through fish-mediated alteration of herbivory pressure by zooplankton. Those effects are either 
due to a reduction of zooplankton biomass (Carpenter and Kitchell, 1993; Brett and Goldman, 1996; Bertolo et al., 2000), or to an alteration of the specific composition of zooplankton communities without any change in zooplankton biomass (Bertolo et al., 1999b; Okun et al., 2008). The paradigm of trophic cascades has led to the development of ecological techniques such as 'biomanipulations', aimed at reducing phytoplankton biomass and slowing down deleterious effects of eutrophication. Variability in their efficiency might have been dependent upon food-web complexity. Indeed, Pinel-Alloul et al. (1998) emphasized that a complete gradient, from strong community-level cascades to weak species-level cascades with complex indirect effects, could be observed in both temperate and tropical lacustrine systems.

Yet, community-level cascades might not frequently occur in the tropics, and many difficulties remain to simply transfer trophic cascade theory from temperate to tropical lakes (Lazzaro, 1997; Jeppesen et al., 2005). Several arguments predicting divergences between top-down effects in temperate and tropical ecosystems have been proposed. In particular, tropical lakes might be characterized by a lack of key herbivorous zooplankton species such as Daphnia (Lazzaro, 1997), an absence of seasonality in fish reproduction (van Leeuwen et al., 2007), a higher frequency of blooms of inedible cyanobacteria (Rondel et al., 2008), and a greater occurrence of fish omnivory (Fernando, 1994). However, published experimental studies testing ecological processes driving the strength of trophic cascades in tropical systems remain very rare.

Besides, benefiting from the development of the ecological stoichiometry theory (Elser et al., 1996; Sterner and Elser, 2002), other indirect effects have been suggested to contribute to the outcome of food-web manipulations. In particular, consumer-driven nutrient recycling (Vanni and Layne, 1997; Elser and Urabe, 1999; Vanni, 2002) has been shown to be a significant process in determining the total availability of inorganic resources for phytoplankton growth. Due to stoichiometric constraints, this process may also alter the relative availabilities of nutrients. Nutrients are recycled as a function of consumer elemental compositions. Nutrients in excess in consumer food relatively to consumer needs are released in larger proportion than limiting nutrients (Elser and Urabe, 1999; Vanni, 2002; Vanni et al., 2002). Consequently, it seems essential to consider alteration of inorganic nutrient availability following modifications of food-web structure as being an indirect consequence of 'top-down' effects. For example, changes in zooplanktivorous fish density could alter quantitatively and qualitatively zooplankton nutrient excretion by modifying the biomass and specific composition of zooplankton communities. Moreover, fish per se represent important sources (Schindler, 1992; Kraft, 1993; Starling et al., 2002; Figueredo and Giani, 2005; Vanni et al., 2006) or sinks (Griffiths, 2006; Sereda et al., 2008) of nutrients.

Primary producers appear frequently P-limited in temperate lakes (Schindler, 1977), but N-limited in tropical regions (Ryding and Rast, 1989; Lewis, 1996; Talling and
Lemoalle, 1998; Downing et al., 1999). This latitudinal disparity in the nature of mineral limitation should induce stoichiometric discrepancies, such as differences in nutrient recycling by zooplankton and fish between temperate and tropical ecosystems. To our knowledge, experimental comparisons of the roles of food-web structure and stoichiometric constraints on trophic cascades in temperate and tropical lakes have never been explicitly addressed.

In this article, we compared the results of two mesocosm experiments carried out either in temperate or in tropical areas, each manipulating food-web structure via the presence $v s$. absence of fish. We discuss top-down effects and their potential differential consequences on nutrient recycling and phytoplankton growth in temperate and tropical aquatic ecosystems, in the light of ecological stoichiometry theory.

\section{Materials and methods}

\section{Study site and experimental design}

\section{Temperate experiment}

Here, we present results over the first 4 months of an experiment that took place in Lake Créteil $\left(48^{\circ} 46^{\prime} 37^{\prime \prime} \mathrm{N}\right.$, $2^{\circ} 26^{\prime} 47^{\prime \prime} \mathrm{E}$ ), using a floating rectangular pontoon designed for mesocosm experiments. Lake Créteil is a small (42-ha), shallow (4-m mean depth, 6-m maximal depth) mesotrophic (3-42 $\mu \mathrm{g}$ chl- $a$. $\mathrm{L}^{-1}$ during the first four-month experimental period, mean value $17.3 \mu \mathrm{g}$ chl- $\left.a . \mathrm{L}^{-1}\right)$ sand-pit lake situated $15 \mathrm{~km}$ southeast of Paris, France. Eight enclosures, made of translucent polyethylene reinforced with nylon mesh, were suspended inside the pontoon, $25 \mathrm{~cm}$ above the lake surface. Each enclosure representing a volume of roughly $40 \mathrm{~m}^{3}(3 \times 3 \mathrm{~m}, 4.5-\mathrm{m}$ depth) was completely sealed at the bottom. The enclosures were filled with water pumped out of the lake. A 1-mm mesh was placed at the end of the pump pipe to avoid entry of large particles within enclosures. To minimize seston heterogeneity, enclosures were filled in sequential steps between 28 and 29 June 2005. At the beginning of the experiment, phytoplankton biomass reached $5.85 \mu \mathrm{g}$ chl-a. $\mathrm{L}^{-1}$, and initial zooplankton biomass represented $314 \mu \mathrm{g}$ DW.L ${ }^{-1}$. To establish two different food-web structures, on 8 July 2005, we added forty $0+$ roach per enclosure (Rutilus rutilus L., Cyprinidae; $42.6 \pm 2.7 \mathrm{~mm} \mathrm{SL}, 0.66 \pm 0.15 \mathrm{~g}$ $\mathrm{WW}$, resulting in one fish. $\mathrm{m}^{-3}$ ), the most common planktivorous fish in European temperate lakes, in half of the enclosures. Final roach biomasses (i.e., $7.3 \pm 0.2 \mathrm{~g}$ $\mathrm{WW} \cdot \mathrm{m}^{-3}$ or $256 \pm 7 \mathrm{~kg} \cdot \mathrm{ha}^{-1}$, as mean $\pm \mathrm{SE}$ ) were typical of zooplanktivores in mesotrophic temperate lakes (Lacroix and Lescher-Moutoué, 1991). Each fishless and fish treatment was replicated four times. To avoid nutrient depletion, we enriched enclosures weekly with inorganic fertilizers. Nutrients were added as a liquid mixture of sodium nitrate $\left(\mathrm{NaNO}_{3}\right)$ and potassium phosphate $\left(\mathrm{KH}_{2} \mathrm{PO}_{4}\right)$ using a $\mathrm{N}$ :P molar ratio of $20: 1$, i.e., a load of $2 \mu \mathrm{M}$ N.L ${ }^{-1}$.day ${ }^{-1}$, and a $0.1 \mu \mathrm{M} . \mathrm{L}^{-1}$.day ${ }^{-1}$. This ratio 
matches the lower end of the range of ratios observed in Lake Créteil. Supplementary information on the experiment can be found in Danger et al. (2008).

\section{Tropical experiment}

We carried out the experiment during the dry season, starting on 24 April 2006 at the IRD-ISRA (French Institute of Research for Development - Senegalese Institute of Agronomy Research) campus in Dakar, Senegal $\left(14^{\circ} 42^{\prime} 11^{\prime \prime} \mathrm{N}, 17^{\circ} 25^{\prime} 31^{\prime \prime} \mathrm{W}\right)$. The experiment was performed in six $8-\mathrm{m}^{3}$ above-ground cylindrical tanks (Recolast impermeabilizacões Ltda., Guarulhos, SP, Brazil; Ø 3.2 m, $1.0-\mathrm{m}$ deep) made of a galvanized iron sheet internally coated with a PVC liner. Tanks were filled in sequential steps with water pumped from Dakar-Bango reservoir $\left(16^{\circ} 3^{\prime} 26^{\prime \prime} \mathrm{N}, 16^{\circ} 27^{\prime} 20^{\prime \prime} \mathrm{W}\right)$, a shallow mesotrophic tropical reservoir $\left(0.8 \mathrm{~km}^{2}\right.$, c.a. $3.2 \mathrm{Mm}^{3}$, 4-m mean depth, $5.5-\mathrm{m}$ maximum depth, 14-36 $\mu \mathrm{g}$ chl- $a . \mathrm{L}^{-1}$ during the experimental period, mean value $22 \mu \mathrm{g}$ chl-a. $\mathrm{L}^{-1}$ ), near Saint Louis (300 km North), and transported using a tank truck. To stimulate the development of the zooplankton population damaged during pumping and transportation, tow-netted reservoir zooplankton was inoculated at natural community density into each tank before fish stocking. At the beginning of the experiment, phytoplankton biomass reached $13.6 \mu \mathrm{g}$ chl- $a . \mathrm{L}^{-1}$. To prevent anoxia events in such shallow enclosures, the surface water of each tank was circulated daily during four 30 -min periods, using a submersible electropump. To avoid nutrient depletion, we enriched tanks every second day by adding a liquid mixture of sodium nitrate $\left(\mathrm{NH}_{4} \mathrm{NO}_{3}\right)$ and potassium phosphate $\left(\mathrm{KH}_{2} \mathrm{PO}_{4}\right)$ using a $\mathrm{N}: \mathrm{P}$ molar ratio of $10: 1$, quite typical of Dakar-Bango reservoir (Kâ, 2006), i.e., a load of $2 \mu \mathrm{M} \mathrm{N} . \mathrm{L}^{-1}$.day ${ }^{-1}$ and $0.2 \mu \mathrm{M} \mathrm{P.L^{-1 } \text { .day }}{ }^{-1}$. On April 25, we added six $0+$ Nile tilapia (Oreochromis niloticus L., Cichlidae; $40.6 \pm 2.2 \mathrm{~g} \mathrm{WW}$ ) in half of the tanks $\left(<1\right.$ fish. $\left.\mathrm{m}^{-3}\right)$, resulting in an initial biomass of $31.6 \pm 0.3 \mathrm{~g} \cdot \mathrm{m}^{-3}$ or $228 \pm 2 \mathrm{~kg} \cdot \mathrm{ha}^{-1}$ that remained roughly constant throughout the experiment. This cichlid species is considered as a model of filter-feeding omnivorous fish, widespread in freshwater systems of Senegal. Note that fish biomasses per unit volume were more than 4times higher in the tropical than in the temperate experiment, which is quite representative of commonly observed differences between the two types of ecosystems (Jeppesen et al., 2005). Differences in foraging behaviour between the two model-fish chosen in our experiments are also considered as representative of fish communities in the two types of media, as previously underlined by Fernando (1994) and more recently by Jeppesen et al. (2005).

\section{Sampling and analyses}

\section{Water parameters}

To yield comparable data in both experiments, we measured the same parameters using similar protocols.
Phytoplankton biomasses were assessed in situ as the mean of two vertical profiles using an in vivo autofluorescence BBE-Moldaenke submersible spectrofluorometer (Kronshagen, Germany). This probe segregates the biomasses of four major phytoplankton groups (Chlorophytes, Cyanobacteria, Diatoms plus Dinophytes, and Cryptophytes), assessed in equivalent $\mu \mathrm{g}$ chl- $a . \mathrm{L}^{-1}$. To evaluate nutrient availability, pooled water samples from each enclosure were filtered onto $\mathrm{GF} / \mathrm{F}$ filters, and dissolved inorganic phosphorus and nitrogen were measured using classical colorimetric methods.

\section{Zooplankton and seston}

Zooplankton samples were collected monthly in temperate enclosures using a 2-L Friedinger bottle. On each sampling date, a total volume of $32 \mathrm{~L}$ was collected from each enclosure, pooling samples from several depths and positions in the water column. The samples were filtered onto $50-\mu \mathrm{m}$ filters and zooplankton was preserved in $4 \%$ formalin-sucrose. Zooplankton individuals from the eight enclosures were identified and counted under a stereomicroscope on subsamples at different appropriate dilutions, using Dolfuss chambers. For specific composition analyses, density data for each taxonomic group were converted into dry biomasses from mean body weights of organisms assessed from Bertolo et al.'s (1999b) data. In tropical tanks, zooplankton was sampled on two dates (days 24 and 30) at night-time (20:00-22:00) using two vertical tows (side, center) of a conical $63-\mu \mathrm{m}$ mesh net (Ø $30 \mathrm{~cm})$. Biomasses of taxonomic groups were computed from specific length-dry weight relationships, established by M. Pagano and S. Kâ (unpublished data) on DakarBango reservoir and Lake Guiers. Composite samples were preserved in 5\% sucrose-formalin, and counted under a stereomicroscope.

In temperate enclosures, zooplankton biomass and elemental composition were determined monthly by sampling 96 litres of water at different depths and positions in each enclosure with a 2 -L Friedinger bottle. In tropical tanks, zooplankton was sampled twice (on days 24 and 30) during the experiment using two vertical tows (side, center) of the conical $63-\mu \mathrm{m}$ mesh net described above. The zooplankton of all samples was gently concentrated onto a 50- $\mu \mathrm{m}$ filter, placed on a pre-weighted GF/A filter, and dried at $60{ }^{\circ} \mathrm{C}$ for 12 hours. Dry zooplankton was then grinded, before being analysed for its stoichiometric composition. To determine seston concentration and elemental composition in both experiments, water samples were taken from the whole column in each enclosure. Samples were pre-filtered through $50-\mu \mathrm{m}$ filters to eliminate zooplankton, filtered on pre-weighted $\mathrm{GF} / \mathrm{F}$ glass-fibre filters (nominal cut-off: $0.7 \mu \mathrm{m}$ ), and then dehydrated for 12 hours in an oven at $60^{\circ} \mathrm{C}$. Dry filters were re-weighted to determine seston mass, and stored in dry conditions until analyses.

Both zooplankton and seston dried-samples were then used to quantify the percentages of carbon and nitrogen contained in organic matter using a $\mathrm{CHN}$ elementary 
analyser (NA 1500 Series 2, Fisons, Manchester, UK). Organic P content was determined after oxidation with sodium persulfate. All $\mathrm{C}: \mathrm{N}: \mathrm{P}$ ratios were expressed as molar ratios.

\section{Nutrient limitation tests}

In both tropical and temperate experiments, we experimentally determined the nature of the mineral limitation of phytoplankton communities. Limitation tests permit to determine which mineral element limits the whole phytoplankton community growth by comparing community biomass after different nutrient additions to unenriched controls (for more details on community level limitations, see Arrigo, 2005). In temperate enclosures, limitation tests were carried out on 29 July, one month after the beginning of the experiment. Water pooled from the whole water column was collected from each enclosure, filtered through a $50-\mu \mathrm{m}$ mesh net to remove zooplankton, and distributed into four 1-L glass bottles. Bottles were allocated to four treatments: C (control without enrichment), $\mathrm{N}$ (enrichment at $100 \mu \mathrm{M}$ N.L $\mathrm{L}^{-1}$ with $1 \mathrm{~mL}$ of a $\mathrm{NaNO}_{3}$ solution), $\mathrm{P}$ (enrichment at $5 \mu \mathrm{M}$ P. $\mathrm{L}^{-1}$ with $1 \mathrm{~mL}$ of a $\mathrm{KH}_{2} \mathrm{PO}_{4}$ solution), and $\mathrm{N}+\mathrm{P}$ (enrichment with $1 \mathrm{~mL}$ of the combined solutions). Bottles were suspended at $50-\mathrm{cm}$ depth in each enclosure and incubated for four days. Similarly, on 24 May (day 29), $20 \mathrm{~L}$ of water were collected in each tropical tank. After gentle mixing and previous filtering through a $60-\mu \mathrm{m}$ mesh net to remove zooplankton, $4 \mathrm{~L}$ of water were split up into four transparent plastic cans. Cans were allocated to four treatments: $\mathrm{C}$ (control without enrichment), $\mathrm{N}$ (enrichment at $5 \mu \mathrm{M} \mathrm{N} . \mathrm{L}^{-1}$ with $1 \mathrm{~mL}$ of a $\mathrm{NH}_{4} \mathrm{NO}_{3}$ solution), $\mathrm{P}$ (enrichment at $0.5 \mu \mathrm{M}$ P.L $\mathrm{L}^{-1}$ with $1 \mathrm{~mL}$ of a $\mathrm{KH}_{2} \mathrm{PO}_{4}$ solution), and $\mathrm{N}+\mathrm{P}$ (enrichment with $1 \mathrm{~mL}$ of the combined solutions). The four cans, the openings of which were covered with a mosquito mesh to avoid colonization by insects, were then hanged at the surface of tank water and incubated in sub-surface for two days.

In both temperate and tropical experiments, phytoplankton biomass responses to the enrichment treatments were assessed using in vivo auto-fluorescence measurements by pouring ca. $0.5 \mathrm{~L}$ of water, previously gently mixed, into a PVC pipe containing the BBE fluroroprobe without its external shield. The standardized percentage difference between the total chlorophyll- $a$ concentrations in bottles with nutrient enrichment $(\mathrm{E}$, with $\mathrm{E}$ as $\mathrm{N}, \mathrm{P}$, or $\mathrm{N}+\mathrm{P}$ ) and control bottles (C) were computed as $(\mathrm{E}-\mathrm{C}) * 100 / \mathrm{C}$ for each enclosure.

\section{Statistical analyses}

For both experiments, we tested for differences between the mean fishless and fish treatments by using oneway repeated-measures ANOVAs $(n=4$ and 3 replicates for temperate and tropical experiments, respectively) with a time trial factor (4 and 2 sampling dates, i.e., days 30, 60,
90, and 120, and days 24 and 30, respectively). Statistical tests were performed using SuperANOVA v.1.11 (Abacus Concepts 1991, Berkeley, CA, USA) on non-transformed data. To test for differences in specific composition of phytoplankton and zooplankton communities, we carried out one-way ANOVAs (fish presence or absence) on the mean proportions of representative groups. To analyse the results of the limitation tests we performed two-way ANOVAs (fish presence/absence and three nutrient levels: $\mathrm{N}, \mathrm{P}$, and $\mathrm{N}+\mathrm{P} ; n=4$ and 3 replicates for temperate and tropical experiments, respectively). Yet, we performed Tukey post-hoc tests to compare differential responses of phytoplankton to $\mathrm{N}, \mathrm{P}$, and $\mathrm{N}+\mathrm{P}$ additions. We also carried out comparisons between means and zero to test for the effects of nutrient additions on phytoplankton biomass as compared to control values. We chose a threshold significance level of $\alpha=0.05$, and showed mean values \pm SE.

\section{Results}

\section{Fish effects on food-web structure}

On an areal basis, final fish biomasses were similar between the temperate and tropical experiments $(25.6 \pm 0.7$ and $22.8 \pm 0.2 \mathrm{~g} \mathrm{WW} . \mathrm{m}^{-2}$, respectively). However, due to difference in the depth of the experimental units $(4.5 \mathrm{~m}$ for enclosures $v s .1 .0 \mathrm{~m}$ for tanks), plus rapid growth of juvenile roach as compared to the nearly null growth of Nile tilapia fingerlings, on a volumetric basis, final fish biomasses resulted only 3 -fold higher in tropical than in temperate experiments (Fig. 1a). Fish had no significant effect on zooplankton biomass in either temperate or tropical system, but zooplankton biomass was roughly 6-fold higher in temperate than in tropical mesocosms (Fig. 1b). Specific composition of zooplankton communities was altered by fish presence in both experiments (Fig. 2). In the temperate experiment, the proportions of calanoids, cyclopoids, small herbivores (rotifers and nauplii), and small cladocerans did not differ significantly between treatments. By contrast, large cladocerans, such as Daphnia and Diaphanosoma, were 15-fold more abundant in fishless than in fish enclosures $(P=0.005)$. In the tropical experiment, we solely found 3 major groups of zooplankton. Large cladocerans were nearly missing in all enclosures (less than $0.1 \%$ of zooplankton community biomass), and calanoids were scarce. Due to high variability, there was no significant effect of fish on the cyclopoid proportion $(P=0.14)$ in the overall zooplankton biomass. Nevertheless, there was a significantly higher proportion of rotifers and small cladocerans in fishless than in fish tanks $(P=0.04$ and $P=0.009$, respectively).

Fish had positive effects on phytoplankton biomass in both temperate and tropical experiments (Fig. 1c). In the temperate experiment, phytoplankton biomass was more than eight-fold higher in fish than in fishless enclosures. In the tropical experiment, fish only increased phytoplankton biomass by less than twofold as compared to control 


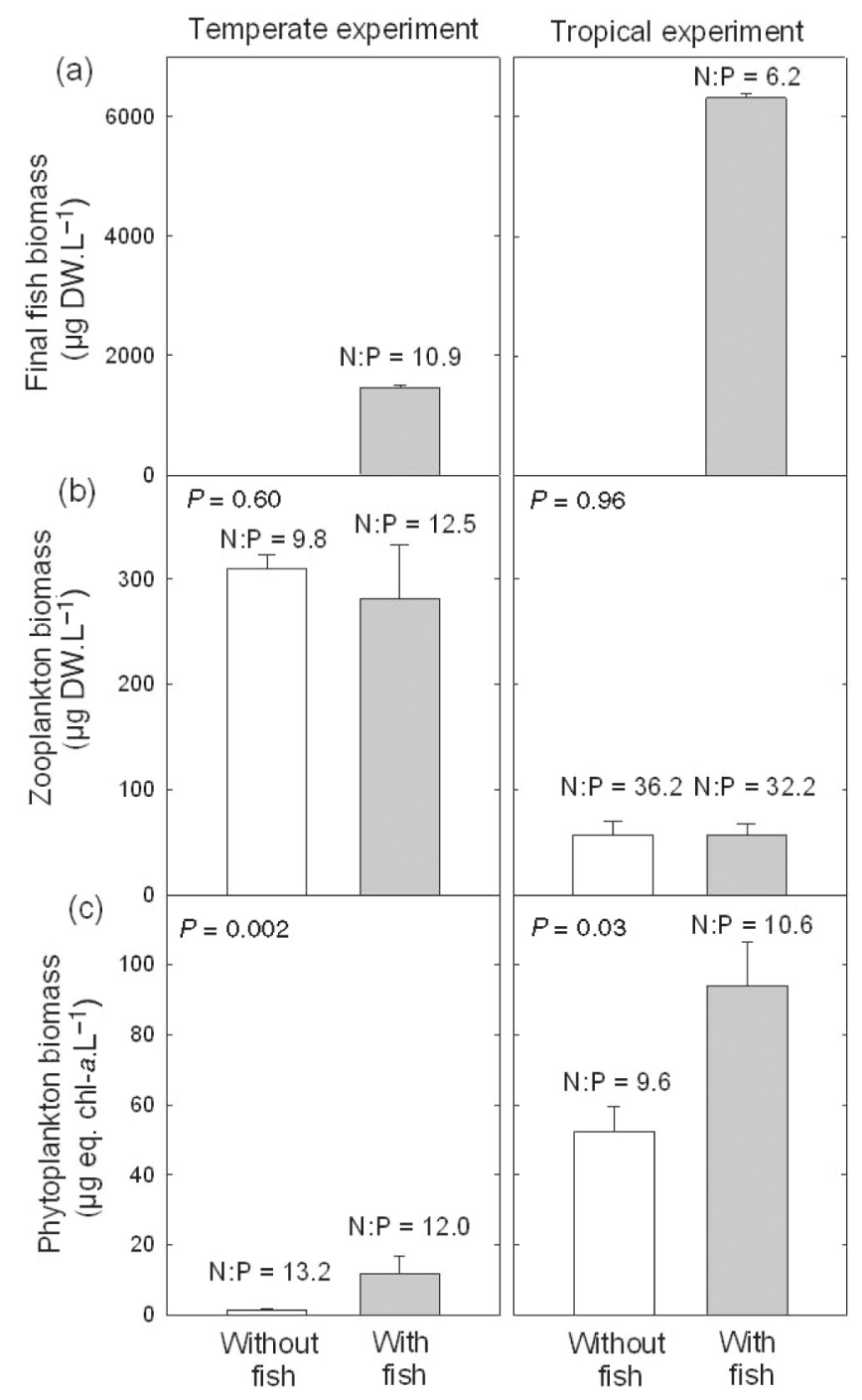

Fig. 1. Mean $\pm \mathrm{SE}$ biomasses of (a) fish dry weight, (b) zooplankton dry weight, and (c) phytoplankton as chlorophyll- $a$ concentration, on a comparable volumetric basis, in the fishless and fish treatments of the temperate and tropical experiments. Phytoplankton and zooplankton data correspond to the mean values of 4 and 2 sampling dates in temperate and tropical experiments, respectively. Molar N:P ratios of fish (based on Dantas and Attayde, 2007), zooplankton, and seston are shown on the top of corresponding graphs.

tanks. Regardless of the treatment, phytoplankton biomass was much higher in tropical than in temperate experiments, with values of tropical control tanks reaching fivefold that of temperate fish enclosures. In both experiments, green algae dominated the biomass of phytoplankton communities (more than $60 \%$, Fig. 3) regardless of treatment. They were significantly less abundant in the control than in the fish tanks in the tropical experiment $(P=0.009)$ but not in the temperate experiment $(P=0.20)$. Cyanobacteria never appeared as a dominant group throughout the experiments. However, cyanobacteria were significantly more abundant in the control of the temperate experiment $(P=0.04)$ and in the fish treatment of

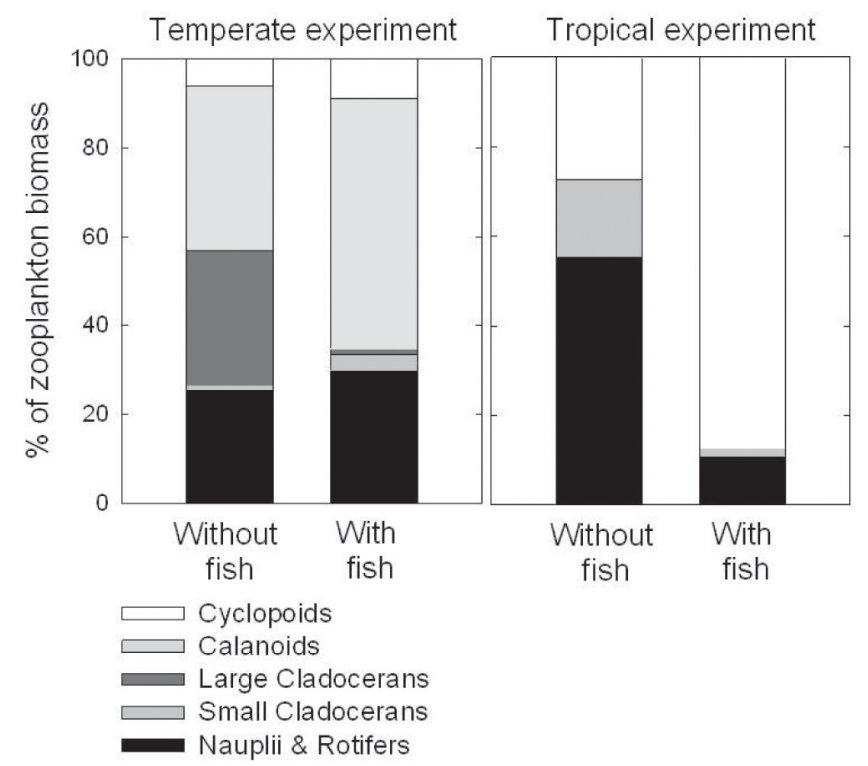

Fig. 2. Mean biomass composition of zooplankton communities in the temperate and tropical experiments, as percents of major taxonomic groups.

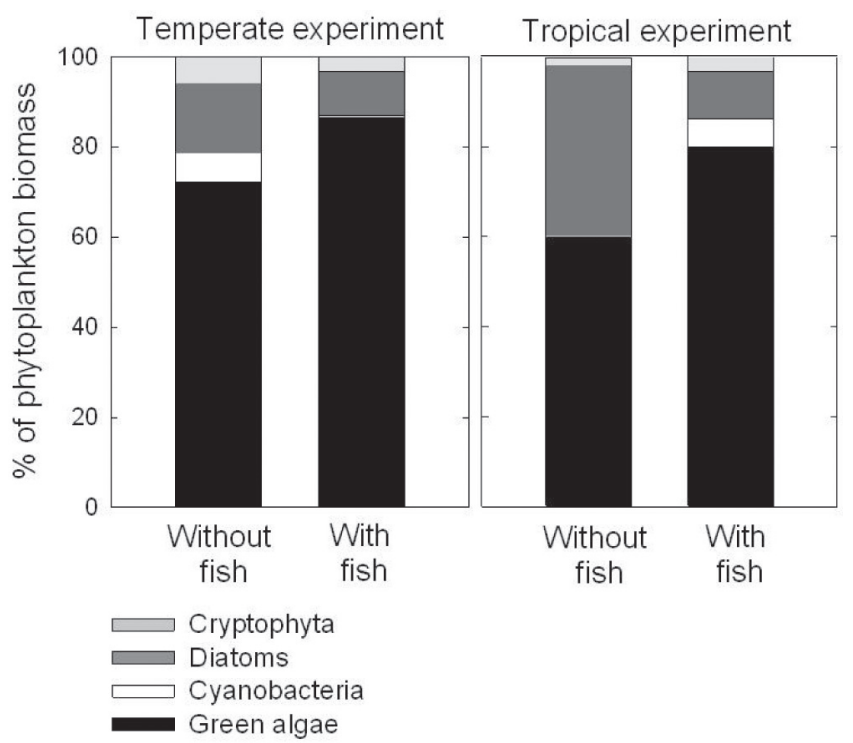

Fig. 3. Mean biomass composition of phytoplankton communities in the temperate and tropical experiments, as percents of equivalent chlorophyll- $a$ concentrations for major taxonomic groups identified by the BBE-Moldaenke spectrofluorometer.

the tropical experiment $(P=0.01)$. In the tropical experiment, diatoms represented greater proportions of phytoplankton biomass in fishless than in fish enclosures $(P=$ $0.001)$ but not in temperate enclosures $(P=0.45)$. Cryptophytes always represented small proportions of phytoplankton communities $(<5 \%)$ in both temperate and tropical experiments and were significantly higher in fish than in control tanks of the tropical experiment $(P=$ $0.0003)$ but did not differ between treatments in temperate experiment $(P=0.43)$. 


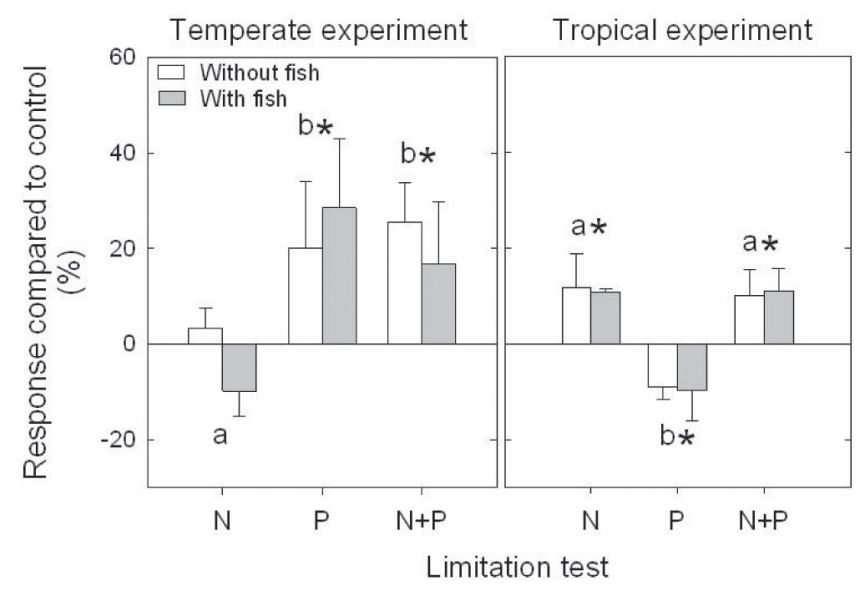

Fig. 4. Mean \pm SE phytoplankton responses to the limitation tests for the temperate and tropical experiments, measured using the BBE-Moldaenke spectrofluorometer. Abbreviations: $\mathrm{N}=$ nitrogen enrichment; $\mathrm{P}=$ phosphorus enrichment; $\mathrm{N}+\mathrm{P}=$ nitrogen and phosphorus enrichment. For each enrichment (E), response is computed as percent increase (positive) or decrease (negative) in relation to the non-enriched control level $(\mathrm{C})$, i.e., $(\mathrm{E}-\mathrm{C}) * 100 / \mathrm{C}$. Limiting factors are revealed by significant positive increases. Difference in quantitative responses between nutrient additions are indicated by a letter, based on Tukey posthoc tests. Significant positive and negative responses (i.e., differences with the zero value) are indicated by an asterisk.

\section{Phytoplankton nutrient limitation}

In both temperate and tropical experiments, fish had no significant effect on the nature of the limiting nutrient for phytoplankton $(P=0.61$ and $P=0.96$, respectively; Fig. 4). However, significant effects of nutrient additions $(P=0.03$ and $P=0.002$, in temperate and tropical experiments, respectively) revealed differences in the nature of the limiting nutrient between temperate and tropical systems. In temperate enclosures, phosphorus addition (alone and in combination with nitrogen) led to significant increase in phytoplankton biomass (i.e. significantly different from zero, $P=0.03$ for $P$-addition, and $P=0.02$ for $\mathrm{N}+\mathrm{P}$ addition). By contrast, phytoplankton biomass was stimulated by the addition of nitrogen in tropical tanks ( $P=0.02$ for N-addition, and $P=0.03$ for $\mathrm{N}+\mathrm{P}$ addition). In tropical limitation tests, we also observed a significant decrease in phytoplankton biomass as compared to control when adding phosphorus $(P=0.02)$.

\section{Organism elemental compositions}

Elemental compositions were measured for seston and zooplankton communities in both experiments (see Fig. 1). In the temperate experiment, zooplankton $\mathrm{N}: \mathrm{P}$ ratios were significantly lower in fishless than in fish enclosures $(P=$ $0.004)$. We found no difference in zooplankton $\mathrm{N}: \mathrm{P}$ ratios between treatments of the tropical experiment $(P=0.56)$, but $\mathrm{N}: \mathrm{P}$ ratios tended to be higher in the tropical than in the temperate experiment. Seston $\mathrm{N}: \mathrm{P}$ ratios seemed unaffected by fish presence in both experiments $(P=0.57$ and $P=0.45$ in temperate and tropical experiments, respectively), but exhibited slightly higher values in temperate than in tropical systems. Values of $\mathrm{N}: \mathrm{P}$ ratios shown on Fig. 1 for roach and tilapia were derived from the literature (Dantas and Attayde, 2007). Both fish, and especially tilapia, were P-rich and had relatively low $\mathrm{N}: \mathrm{P}$ ratios.

\section{Discussion}

\section{Community-level patterns}

Temperate and tropical systems were characterized by inverse plankton biomass patterns. High biomasses of zooplankton and low biomasses of phytoplankton occurred in temperate enclosures, and conversely in tropical tanks. The low depth of our tropical tanks could not explain the low zooplankton biomass per unit of volume, as an inverse pattern was typically found in nature or in experimental systems (see Bertolo et al., 1999a). Kâ (2006) also pointed out the low total biomasses of zooplankton in Dakar-Bango reservoir $\left(8-103 \mu \mathrm{g}\right.$ DW.L $\left.{ }^{-1}\right)$ and Lake Guiers $\left(10-57 \mu \mathrm{g}\right.$ DW. $\left.\mathrm{L}^{-1}\right)$ (data obtained assuming that $\mathrm{C}=45 \%$ of zooplankton dry weight, Talling and Lemoalle, 1998). In their syntheses, Nilssen (1984) and Fernando (1994) had already underlined that the zooplankton to phytoplankton biomass ratio should be lower in the tropics. The very high level of chlorophyll- $a$ in our tropical tanks strongly suggests that primary producers were not controlled by herbivory. This weak global topdown control of phytoplankton might be typical of tropical ecosystems, and related to the presence of large poorly edible phytoplankton (Lazzaro et al., 2003; Rondel et al., 2008), to the small body-size of zooplankton (Gliwicz, 1994) and scarcity of large cladocera (Gillooly and Dodson, 2000), and to the low total biomass of zooplankton (Kâ, 2006). Conversely, dominance of small algal cells (unpublished data) and higher zooplankton biomass should have favoured stronger top-down control in our temperate enclosures.

Our results demonstrate the existence of trophic cascades from fish to planktonic primary producers at both latitudes. In both experiments, trophic cascades were never mediated by a reduction of zooplankton biomass, in contrast to Brett and Goldman's (1996) meta-analysis, but in accordance with the results of Bertolo et al. (1999b) with roach and Okun et al. (2008) with Nile tilapia, in temperate and tropical experiments, respectively. Moreover, relative difference in phytoplankton biomass between fishless and fish enclosures was greater in temperate than in tropical systems, as underlined by Okun et al. (2008). The final fish biomasses in these two experiments are rather conservative for omnivorous fish such as cyprinids (Lacroix and Lescher-Moutoué, 1991) and especially tilapia (Fernando, 1994). Note that when comparing initial and final fish biomass, fish growth rates were 
higher in temperate than in tropical enclosures. This can probably be related to the differences in initial mean size of the two species. Roach were initially introduced in temperate enclosures as neonates, characterized by important exponential growth rates. Tilapias were bigger at the beginning of the tropical experiment, and had certainly already reached a lower growth rate.

\section{Shift in plankton species}

In the temperate experiment, fish treatment clearly induced changes in the specific composition of zooplankton communities, as found in previous experiments with roach (Bertolo et al., 1999b). Roach significantly reduced the biomass of large cladocerans, did not modify the biomass of small herbivores (nauplii, rotifers, and small cladocerans), and tended to increase the biomass of copepods that better escape cyprinid predation (Lacroix et al., 1996). Bertolo et al. (1999b) demonstrated that similar shifts in zooplankton community structure were sufficient to induce a two-fold increase in filtration rates by the total zooplankton community in the fishless as compared to the roach enclosures. Thus, it is highly probable that primary producers were strongly controlled by herbivorous zooplankton in fishless enclosures.

In contrast, the presence of Nile tilapia fingerlings significantly reduced the relative importance of small zooplankton (rotifers, nauplii, and small cladocerans) within the tropical zooplankton communities. Nile tilapia fingerlings are able to feed on microphytoplankton $(\geq 20 \mu \mathrm{m})$ and detritus from bottom sediment, plus, incidentally, on small poorly evasive zooplankton (Batjakas et al., 1997). Nile tilapia might only have a significant effect on larger zooplankton at their youngest fry and juvenile stages (Rondel et al., 2008), when they also visually feed on zooplankton. Although the fish effect was not significant, copepods (particularly cyclopoids) tended to be more abundant in presence than in absence of Nile tilapia. This unexpected result might not only be related to the poor capture ability of fast moving copepods by filtering tilapia, but also to the high abundance of larvae of odonates and Chaoborus, Notonectidae and water mites observed in our fishless tropical tanks. This suggests that large zooplankton might have been partly controlled by these carnivorous macroinvertebrates. Due to their terrestrial surroundings, our shallow above-ground tropical tanks were very accessible to various macroinvertebrates, in particular insects, and tended to mimic littoral conditions. Thus, these characteristics did not necessarily reflect typical differences between temperate and tropical lakes. Yet, as previously underlined, differences in zooplankton community structure cannot explain trophic cascades in our tropical systems, due to low grazing abilities and very low biomasses of dominant zooplankton taxa. Moreover, zooplankton tended to be even smaller and dominated by less efficient grazers in absence of fish than in tilapia enclosures. In contrast, Okun et al. (2008) showed that omnivorous tilapia significantly decreased the abundance of large cladocerans, increased the abundance of small algae and decreased water transparency in tropical mesocosms, as predicted by trophic cascade theory. However, prevalent large phytoplankton did not significantly respond, and thus community-level trophic cascades were not observed in their experiment.

Fish treatments did not appear to have induced drastic changes in the community structure of primary producers, neither in temperate enclosures nor in tropical tanks. In both experiments, the relative importance of major algal groups was rather similar. Cyanobacteria remained always rare in our experiments. Thus, discrepancies between temperate and tropical experiments were totally independent of these organisms, which can bloom rather independently from zooplankton control and can totally inhibit the cascading fish effects (Rondel et al., 2008).

\section{Limitation patterns in temperate and tropical systems}

The results of the limitation tests show opposite patterns in temperate and tropical experiments. This is quite representative of the classical limitation patterns found along latitudinal gradients, phytoplankton being mainly limited by phosphorus in temperate systems, and by nitrogen in tropical lakes (Downing et al., 1999; Lewis, 2002). These opposite limitation patterns are consistent with the values of the dissolved nitrogen to soluble reactive phosphorus ratios (DIN:SRP) measured in our temperate $(100.0 \pm 11.7)$ and tropical $(13.6 \pm 2.1)$ systems (unpublished data). Two explanations to these functionally important divergences can be put forward. First, tropical lakes could receive less nitrogen supply than temperate lakes. Second, nitrogen internal loss could be higher in tropical than in temperate lakes. Recent studies (Lewis, 2002; Schaefer and Alber, 2007) suggest that the second explanation is the most probable, denitrification increasing with temperature and being a major factor of $\mathrm{N}$-loss in tropical watersheds. We also observed a significant negative effect of P-addition in tropical limitation test. This could be explained by rapid immobilization of dissolved nutrients by bacteria, which are better competitors for phosphorus than phytoplankton (Danger et al., 2007a). By using the supplied phosphorus, bacteria have also uptaken nitrogen, thus increasing further N-limitation for phytoplankton.

\section{Organism stoichiometry}

At first hand, the lower $\mathrm{N}: \mathrm{P}$ ratios of seston in our tropical systems were consistent with phytoplankton $\mathrm{N}$-limitation, and conversely for our temperate P-limited systems. Primary producers are not homeostatic and their composition partly reflects nutrient limitation (Danger et al., 2007b): algal cells tend to accumulate nutrients in excess ('luxury consumption' sensu Rhee, 1978). However, differences between temperate and tropical systems 
were weak. Seston N:P ratio was rather low in temperate enclosures when considering the low SRP concentrations, typical of Lake Créteil during summer (Lacroix et al., 1989). Elrifi and Turpin (1985) showed that cellular requirements increase more quickly for $\mathrm{P}$ than for $\mathrm{N}$ with growth rate, thus diminishing the $\mathrm{N}$ : $\mathrm{P}$ ratio of algal cells (see also Agren, 2004). Zooplankton grazing rate, and thus algal turnover, were probably greater in temperate enclosures than in tropical tanks (see above), thus decreasing algal $\mathrm{N}: \mathrm{P}$ ratio below expectation.

Globally, the zooplankton $\mathrm{N}: \mathrm{P}$ ratio in temperate enclosures was rather low, probably in relation with the greater importance of cladocerans in such systems (Sterner and Elser, 2002). In contrast, the zooplankton N:P ratio was high in tropical systems, which might have resulted from the observed higher copepods to large cladocerans ratio (Sterner and Elser, 2002). However, species-level data on zooplankton stoichiometry are too scarce to infer robust conclusions. As different zooplankton groups have specific elemental compositions (Andersen and Hessen, 1991), alterations in community structure should induce changes in their nutrient mean $\mathrm{N}: \mathrm{P}$ ratios. In agreement with Elser et al.'s (2000) results in biomanipulated lakes, we observed that the zooplankton $\mathrm{N}$ : $\mathrm{P}$ ratio was significantly smaller in absence of roach, probably due to higher importance of cladocerans. We cannot draw definitive conclusions from the absence of fish effect on zooplankton $\mathrm{N}: \mathrm{P}$ ratio in tropical systems owing to the very preliminary nature of our data.

We did not make direct measurements of fish $\mathrm{N}: \mathrm{P}$ ratios. Hendrixson et al. (2007) showed that stoichiometric variations are greater across than within fish species, and that $\mathrm{C}: \mathrm{N}: \mathrm{P}$ stoichiometry is species-dependent, $\mathrm{P}$ content being derived almost entirely from skeletal investment. Moreover, they showed that body phosphorus content depend significantly upon feeding mode $(\% \mathrm{P}$ planktivores $<\%$ P omnivores). Based on Dantas and Attayde's (2007) results, roach $\mathrm{N}: \mathrm{P}$ ratio (10.9) should be almost twofold that of Nile tilapia (6.2).

\section{Nutrient excretion by zooplankton and fish}

For the last two decades, zooplankton and fish have been recognized as particularly important in the nutrient cycling of freshwater ecosystems. Via their excretion, animals can supply nutrients at rates comparable to major lake nutrient sources and consequently deeply affect primary producer growth (e.g. Vanni, 2002). Theoretical and experimental works have shown that $\mathrm{N}: \mathrm{P}$ release ratios are primarily a function of resources $\mathrm{N}: \mathrm{P}$ ratios and secondarily a function of consumer $\mathrm{N}: \mathrm{P}$ ratios (Elser and Urabe, 1999; Torres and Vanni, 2007). In our temperate experiment, zooplankton represented roughly $20 \%$ of fish biomass. Attayde and Hansson (1999) showed that, as predicted by allometry, intrinsic excretion rate of Daphnia was roughly an order of magnitude greater than intrinsic excretion rate of roach. Consequently, by compensation of biomass and excretion ratios, both fish and zooplankton are likely to play a great role in the nutrient recycling in temperate systems. Sarnelle and Knapp (2005) suggested that zooplankton was even more important than fish in consumer-driven nutrient recycling. By contrast, in our tropical tanks, we found relatively low zooplankton biomass, and zooplankton represented less than $1 \%$ of fish biomass in fish enclosures. Therefore, zooplankton contribution to recycling should have been much lower than that of fish.

The $\mathrm{N}$ : P ratio of temperate roach was relatively similar to that of their potential food (zooplankton and seston, see Fig. 1). Conversely, the $\mathrm{N}: \mathrm{P}$ ratio of tropical tilapia was clearly smaller than that of their food. Owing to stoichiometric constraints (Elser and Urabe, 1999), fish excretion $\mathrm{N}: \mathrm{P}$ ratio should have been greater in tropical tanks than in temperate enclosures. Results of preliminary measurements of fish excretion rates in both experiments are in agreement with this hypothesis. Roach excretion $\mathrm{N}: \mathrm{P}$ ratio was $14.6 \pm 0.9$. Tilapia excretion $\mathrm{N}$ : $\mathrm{P}$ ratio was very high, phosphorus being excreted at very low levels (near or under detection limit) and nitrogen excretion representing up to $11.7 \%$ of the daily nitrogen enrichment. Such a fishmediated nitrogen internal loading probably constituted a major mechanism that induced phytoplankton increase in our N-limited tropical systems.

\section{Alternative explanations}

Our temperate experimental enclosures were 4-m deep, while our tropical tanks were 1-m deep. Due to tank shallowness, tilapia might have promoted sediment resuspension, as suggested by Starling et al. (2002) and Okun et al. (2008). From an enclosure experiment with common carp, Cyprinus carpio L., Roozen et al. (2007) suggested that direct resuspension of settled algae might be a factor as important as either nutrient release or possible trophic cascade interactions to explain the increase in phytoplankton biomass in presence of fish. In our tropical tanks, surface water was circulated with submersible pumps four times a day. We verified that water mixing at the surface induced water turbulence in the water column and strongly reduced phytoplankton settling (unpublished results). Moreover, diatom absolute and relative biomasses were smaller in presence than absence of fish. Our results contrast with Roozen et al.'s (2007) where diatoms, which are characterized by a high sedimentation velocity, only increased in density in presence of benthivorous carp. This suggests that algal resuspension by tilapia was probably not the main mechanism explaining the increase in algal biomass in our tropical systems.

\section{Conclusion}

In both temperate and tropical ecosystems, many factors concur in generating trophic cascades, e.g., control of herbivory, consumer-driven differential nutrient recycling, or phytoplankton and sediment resuspension. Our results 
suggest that the relative importance of these factors greatly differs between the two types of ecosystems. Temperate trophic cascades seem mainly driven by fish alterations of zooplankton communities, and resulting modifications of herbivory pressure. In tropical systems, top-down control of phytoplankton by zooplankton communities appears as relatively minor. Our tropical experiment supports that stoichiometric constraints lead to important fish-mediated nitrogen internal loading that could, at least partly, explain the positive effect of fish on N-limited phytoplankton. Divergences in the relative importance of zooplankton and fish excretion and in the nature of nutrient limitation between both systems could represent major differences between temperate and tropical lakes, which have rarely been considered in previous studies. Up to now, only a few tropical studies bring the appropriate data, in particular on stoichiometry of food webs, which would allow robust generalization on the functioning of freshwater temperate and tropical ecosystems. Owing to rapid eutrophication and fish community alterations in tropical lakes, further studies are clearly needed to test the generality of trophic-cascade principles, and furthermore provide theoretical grounds for successful restoration programs based on ecological engineering principles.

Acknowledgements. This work was in part supported by the GIP ECOFOR program (CyBiom Project/Ministère de l'Écologie, de l'Énergie, du Développement durable et de l'Aménagement du territoire) to XL, MD, and GL, by the ANR program (BioFun project) to MD and GL, and, for the tropical experiment, by the research unit CYROCO (UR 167) of IRD (the French Institute of Research for Development) to XL. We are very greatful to the Scientific committee of the "Association Française de Limnologie" for the opportunity to compare the role of stoichiometry in trophic cascades between temperate and tropical lakes, as an introductory oral presentation at the $50^{\text {th }}$ AFL congress in Toulouse (November 2007). We thank Safia Hamiche, Jacques Mériguet, and Abdoulaye Boucar Ndour for laboratory and field technical assistance.

\section{References}

Agren G.I., 2004. The C:N:P stoichiometry of autotrophs theory and observations. Ecol. Lett., 7, 185-191.

Andersen T. and Hessen D.O., 1991. Carbon, nitrogen and phosphorus content of freshwater zooplankton. Limnol. Oceanogr., 36, 807-813.

Arrigo K.R., 2005. Marine microorganisms and global nutrient cycles. Nature, 437, 349-355.

Attayde J.L. and Hansson L.-A., 1999. Effects of nutrient recycling by zooplankton and fish on phytoplankton communities. Oecologia, 121, 47-54.

Attayde J.L. and Hansson L.-A., 2001. Fish-mediated nutrient recycling and the trophic cascade in lakes. Can. J. Fish. Aqua. Sci., 58, 1924-1931.

Batjakas I.E., Edgar R.K. and Kaufman L.S., 1997. Comparative feeding efficiency of indigenous and introduced phytoplanktivores from Lake Victoria: experimental studies on Oreochromis esculentus and Oreochromis niloticus. Hydrobiologia, 347, 75-82.

Bertolo A., Lacroix G. and Lescher-Moutoué F., 1999a. Scaling food chains in aquatic mesocosms: do the effects of depth override the effects of planktivory?. Oecologia, 121, 55-65.

Bertolo A., Lacroix G., Lescher-Moutoué F. and Sala S., 1999b. Effects of physical refuges on fish-plankton interactions. Freshwat. Biol., 41, 795-808.

Bertolo A., Lacroix G., Lescher-Moutoué F. and CardinalLegrand C., 2000. Plankton dynamics in planktivore- and piscivore-dominated mesocosms. Arch. Hydrobiol., 147, 327-349.

Brett M.T. and Goldman C.R., 1996. A meta-analysis of the freshwater trophic cascade. Proc. Natl. Acad. Sci. USA, 93, 7723-7726.

Carpenter S.R. and Kitchell J.F. (eds.), 1993. The Trophic Cascade in Lakes, Cambridge University Press, Cambridge, UK, 385 p.

Danger M., Leflaive J., Oumarou C., Ten-Hage L. and Lacroix G., 2007a. Control of phytoplankton-bacteria interactions by stoichiometric constraints. Oikos, 116, 1079-1086.

Danger M., Oumarou C., Benest D. and Lacroix G., $2007 \mathrm{~b}$. Bacteria can control stoichiometry and nutrient limitation of phytoplankton. Funct. Ecol., 21, 202-210.

Danger M., Lacroix G., Oumarou C., Benest D. and Mériguet J., 2008. Effects of food-web structure on periphyton stoichiometry in eutrophic lakes: A mesocosm study. Freshwat. Biol., 53, 2089-2100.

Dantas M.C. and Attayde J.L., 2007. Nitrogen and phosphorus content of some temperate and tropical freshwater fishes. J. Fish Biol., 70, 100-108.

Downing J.A., Osenberg C.W. and Sarnelle O., 1999. Metaanalysis of marine nutrient-enrichment experiments: variation in the magnitude of nutrient limitation. Ecology, 80, $1157-1167$.

Elrifi I.R. and Turpin D.H., 1985. Steady-state luxury consumption and the concept of optimum nutrient ratios: A study with phosphate and nitrate limited Selenastrum minutum (Chlorophyta). J. Phycol., 21, 592-602.

Elser J.J. and Urabe J., 1999. The stoichiometry of consumerdriven nutrient cycling: theory, observations, and consequences. Ecology, 80, 735-751.

Elser J.J., Dobberfuhl D., Mackay N.A. and Schampel J.H., 1996. Organism size, life history, and N:P stoichiometry: towards a unified view of cellular and ecosystem processes. Bioscience, 46, 674-684.

Elser J.J., Sterner R.W., Galford A.E., Chrzanowski T.H., Findlay D.L., Mills K.H., Paterson M.J., Stainton M.P. and Schindler D.W., 2000. Pelagic C:N:P stoichiometry in a eutrophied lake: responses to a whole-lake food-web manipulation. Ecosystems, 3, 293-307.

Fernando C.H., 1994. Zooplankton, fish and fisheries in tropical freshwaters. Hydrobiologia, 272, 105-123.

Figueredo C.C. and Giani A., 2005. Ecological interactions between Nile tilapia (Oreochromis niloticus, L.) and the phytoplanktonic community of the Furnas Reservoir (Brazil). Freshwat. Biol., 50, 1391-1403.

Gillooly J.F. and Dodson S.I., 2000. Latitudinal patterns in the size distribution and seasonal dynamics of new world, freshwater cladocerans. Limnol. Oceanogr., 45, 22-30. 
Gliwicz Z.M., 1994. Relative significance of direct and indirect effects of predation by planktivorous fish on zooplankton. Hydrobiologia, 272, 201-210.

Griffiths D., 2006. The direct contribution of fish to lake phosphorus cycles. Ecol. Freshwat. Fish, 15, 86-95.

Hendrixson H.A., Sterner R.W. and Kay A.D., 2007. Elemental stoichiometry of freshwater fishes in relation to phylogeny, allometry and ecology. J. Fish Biol., 70, 121-140.

Jeppesen E., Søndergaard M., Mazzeo N., Meerhoff M., Branco C.C., Huszar V. and Scasso F., 2005. Lake restoration and biomanipulation in temperate lakes: relevance for subtropical and tropical lakes. In: Reddy V. (ed.), Tropical eutrophic lakes: their restoration and management, Oxford and IBH Publ. Co. Pvt. Ltd., New Delhi and Science Publishers Inc., New Hampshire, USA, 351-376.

Kâ S., 2006. Communautés zooplanctoniques de deux lacs tropicaux (lac de Guiers et réservoir de Dakar Bango, Sénégal): relations avec les facteurs environnementaux, le phytoplancton et les efflorescences cyanobactériennes. Thèse de l'Université d'Aix-Marseille 1, Sciences de l'Environnement, $212+127 \mathrm{pp}$. (Two volumes).

Kraft C.E., 1993. Phosphorus regeneration by Lake Michigan alewives in the mid-1970s. Trans. Am. Fish. Soc., 122, 749755.

Lacroix G. and Lescher-Moutoué F., 1991. Interaction effects of nutrient loading and density of young-of-the-year cyprinids on eutrophication in a shallow lake: an experimental mesocosm study. Mem. Ist. Ital. Idrobiol., 48, 53-73.

Lacroix G., Boët P., Garnier J., Lescher-Moutoué F., Pourriot R. and Testard P., 1989. Factors controlling the planktonic community in the shallow lake of Créteil, France. Int. Revue Ges. Hydrobiol., 74, 353-370.

Lacroix G., Lescher-Moutoué F. and Pourriot R., 1996. Trophic interactions, nutrient supply, and structure of freshwater pelagic food webs. In: Hochberg M., Clobert J. and Barbault R. (eds.), Aspects in the Genesis and Maintenance of Biological Diversity, Oxford Univ. Press, Oxford, UK, 162-179.

Lazzaro X., 1997. Do the trophic cascade hypothesis and classical biomanipulation approaches apply to tropical lakes and reservoirs? Verh. Internat. Verein. Limnol., 26 , 719-730.

Lazzaro X., Bouvy M., Ribeiro-Filho A., Oliviera V.S., Sales L.T., Vasconcelos A.R.M. and Mata M.R., 2003. Do fish regulate phytoplankton in shallow eutrophic Northeast Brazilian reservoirs?. Freshwat. Biol., 48, 649-668.

Lewis W.M. Jr., 1996. Tropical lakes: how latitude makes a difference. In: Schiemer F. and Boland K.T. (eds.), Perspectives in Tropical Limnology, SPB Academic Publishers, Amsterdam, The Netherlands, 43-64.

Lewis W.M Jr., 2002. Causes for the high frequency of nitrogen limitation in tropical lakes. Verh. Internat. Verein. Limnol., 28, 210-213.

Nilssen J.P., 1984. Tropical lakes-functionnal ecology and future development: the need for a process-orientated approach. Hydrobiologia, 113, 231-242.

Okun N., Brasil J., Attayde J.L. and Costa I.A.S., 2008. Omnivory does not prevent trophic cascades in pelagic food webs. Freshwat. Biol., 53, 129-138.

Pinel-Alloul B., Mazumder A., Lacroix G. and Lazzaro X., 1998. Les réseaux trophiques lacustres: structure, fonctionnement, interactions et variations spatio-temporelles. Rev. Sci. Eau, 11, 163-197.
Polis G.A., 1999. Why are parts of the world green? Multiple factors control productivity and the distribution of biomass. Oikos, 86, 3-15.

Polis G.A., Sears A.L.W., Huxel G.R. and Strong D.R., 2000. When is a trophic cascade a trophic cascade? TREE, 15, 473-475.

Rhee G.-V., 1978. Effects of N:P atomic ratios and nitrate limitation on algal growth, cell composition and nitrate uptake. Limnol. Oceanogr., 23, 10-25.

Rondel C., Arfi R., Corbin C., Le Bihan F., Ndour E.H. and Lazzaro X., 2008. A cyanobacterial bloom prevents fish trophic cascades. Freshwat. Biol., 53, 637-651.

Roozen F.C.J.M., Lurling M., Vlek H., Kraan E.A.J.V.P., Ibelings B.W. and Scheffer M., 2007. Resuspension of algal cells by benthivorous fish boosts phytoplankton biomass and alters community structure in shallow lakes. Freshwat. Biol., 52, 977-987.

Ryding S.O. and Rast W. (eds.), 1989. The Control of Eutrophication of Lakes and Reservoirs, UNESCO, Man and the Biosphere Series, Vol. 1, Parthenon Publishing, Paris, $314 \mathrm{p}$.

Sarnelle O. and Knapp R.A., 2005. Nutrient recycling by fish versus zooplankton grazing as drivers of the trophic cascade in alpine lakes. Limnol. Oceanogr., 50, 2032-2042.

Schaefer S.C. and Alber M., 2007. Temperature controls a latitudinal gradient in the proportion of watershed nitrogen exported to coastal ecosystems. Biogeochemistry, 85, 333-346.

Schindler D.E., 1992. Nutrient regeneration by Sockeye Salmon (Oncorhynchus nerka) fry and subsequent effects on zooplankton and phytoplankton. Can. J. Fish. Aquat. Sci., 49, 2498-2506.

Schindler D.W., 1977. Evolution of phosphorus limitation in lakes. Science, 195, 260-262.

Schmitz O.J., Hambäck P.A. and Bekerman A.P., 2000. Trophic cascades in terrestrial systems: A review of the effects of carnivore removals on plants. Am. Nat., 155, 141153.

Sereda J.M., Hudson J.J., Taylor W.D. and Demers E., 2008. Fish as sources and sinks of nutrients in lakes. Freshwat. Biol., 53, 278-289.

Starling F., Lazzaro X., Cavalcanti C. and Moreira R., 2002. Contribution of omnivorous tilapia to eutrophication of a shallow tropical reservoir: evidence from a fish kill. Freshwat. Biol., 47, 2443-2452.

Sterner R.W. and Elser J.J. (eds.), 2002. Ecological stoichiometry: The biology of elements from molecules to biosphere, Princeton University Press, Princeton, NJ, USA, 439 p.

Strong D.R., 1992. Are trophic cascades all wet? Differentiation and donor-control in speciose ecosystems. Ecology, 73, 747754.

Talling J.F. and Lemoalle J., 1998. Ecological Dynamics of Tropical Inland Waters, Cambridge University Press, Cambridge, $451 \mathrm{p}$.

Torres L.E. and Vanni M.J., 2007. Stoichiometricy of nutrient excretion by fish: interspecific variation in a hypereutrophic lake. Oikos, 116, 259-270.

van Leeuwen E., Lacerot G., van Nes E.H., Hemerik L. and Scheffer M., 2007. Reduced top-down control of phytoplankton in warmer climates can be explained by continuous fish reproduction. Ecol. Model., 206, 205-212. 
Vanni M.J., 2002. Nutrient cycling by animals in freshwater ecosystems. Annu. Rev. Ecol. Syst., 33, 341-370.

Vanni M.J. and Layne C.D., 1997. Nutrient recycling and herbivory as mechanisms in the "top-down" effect of fish on algae in lakes. Ecology, 78, 21-40.

Vanni M.J., Flecker A.S., Hood J.M. and Headworth J.L., 2002. Stoichiometry of nutrient recycling by vertebrates in a tropical stream: linking species identity and ecosystem processes. Ecol. Lett., 5, 285-293.

Vanni M.J., Bowling A.M., Dickman E.M., Hale R.S., Higgins K.A., Horgan M.J., Knoll L.B., Renwick W.H. and Stein R.A., 2006. Nutrient cycling by fish supports relatively more primary production as lake productivity increases. Ecology, 87, 1696-1709. 